Neuro/mages

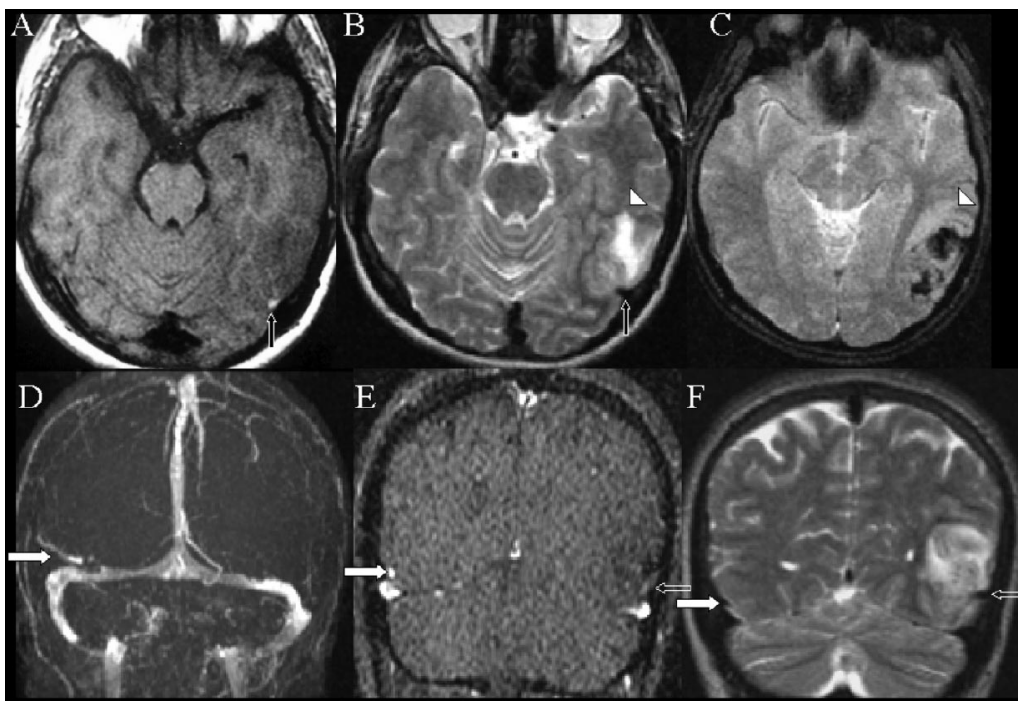

Figure 1. MRI and MR venography: T1weighted axial spin echo imaging (A); T2weighted axial fast spin echo imaging $(B)$; T2*-weighted axial gradient-recalled echo imaging (C); two-dimensional time-of-flight $M R$ venography $(D)$; coronal source image of $M R$ venography (E); T2-weighted coronal fast spin echo imaging $(F)$. Note the hemorrhagic venous infarct in the left posterior temporal lobe (arrowhead). Vein of Labbe is patent on the right side (filled arrow) and occluded on the left side. The thrombus in the vein appears hyperintense on T1 and hypointense on T2weighted images with absent bright signal on time-of-flight source image (open arrow).

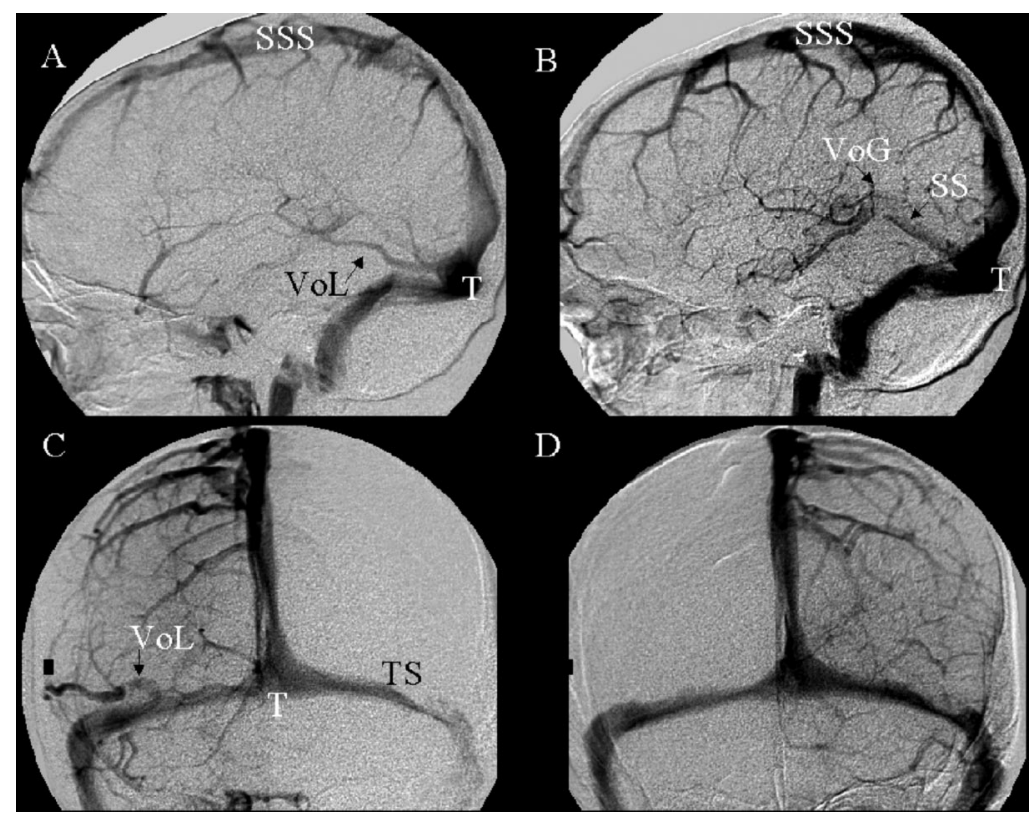

Figure 2. Digital subtraction angiography, venous phase. $(A, C)$ Right carotid injection; ( $B$, D) left carotid injection, lateral and anteroposterior projections. Note the vein of Labbe is not opacified on the left side. SSS = superior sagittal sinus; $S S=$ straight sinus; $T=$ torcula; $T S=$ transverse sinus; $V o L=$ vein of Labbe; VoG $=$ vein of Galen.

\section{Isolated left vein of Labbe thrombosis}

Bejoy Thomas, MD, DNB; Thamburaj Krishnamoorthy, DM; Sukalyan Purkayastha, DM; and Arun Kumar Gupta, MD, Kerala, India

A 23-year-old man developed sudden onset of fever and headache. He was alert but had slight difficulty with naming and had agraphia and acalculia. The provisional diagnosis was viral encephalitis. MRI showed a left posterior temporal hemorrhagic in-

Address correspondence and reprint requests to Dr. B. Thomas, Department of Radiology, SCTIMST, Trivandrum, Kerala, India 695011; e-mail: bejoy@sctimst.ac.in, drbejoy2002@yahoo.com farct with thrombosis of left vein of Labbe (figure 1). This was confirmed by MR venography (figure $1, \mathrm{D}, \mathrm{E}$ ) and digital subtraction angiography (figure 2). Isolated thrombosis of the vein of Labbe has been rarely reported. The left Labbe vein has been most often involved. ${ }^{1}$ The vein of Labbe drains the lateral temporal lobe and empties into the transverse sinus. ${ }^{1,2}$ Thrombosis can cause temporal lobe hemorrhagic infarction, hemorrhage, or edema.

1. Dorndorf D, Wessl K, Kessler C, et al. Thrombosis of right vein of Labbe: radiological and clinical findings. Neuroradiology 1993;35:202-204.

2. Jones BV. Case 62: lobar hemorrhage from thrombosis of the vein of Labbe. Radiology 2003;228:693-696. 


\section{Neurology}

Isolated left vein of Labbe thrombosis

Bejoy Thomas, Thamburaj Krishnamoorthy, Sukalyan Purkayastha, et al. Neurology 2005;65;1135

DOI 10.1212/01.wnl.0000181352.14678.18

\section{This information is current as of October 10, 2005}

\section{Updated Information \&} Services

References

Citations

Subspecialty Collections

Permissions \& Licensing

Reprints including high resolution figures, can be found at: http://n.neurology.org/content/65/7/1135.full

This article cites 2 articles, 0 of which you can access for free at: http://n.neurology.org/content/65/7/1135.full\#ref-list-1

This article has been cited by 3 HighWire-hosted articles: http://n.neurology.org/content/65/7/1135.full\#\#otherarticles

This article, along with others on similar topics, appears in the following collection(s):

Cerebral venous thrombosis

http://n.neurology.org/cgi/collection/cerebral_venous_thrombosis MRI

http://n.neurology.org/cgi/collection/mri

Information about reproducing this article in parts (figures,tables) or in its entirety can be found online at:

http://www.neurology.org/about/about_the_journal\#permissions

Information about ordering reprints can be found online:

http://n.neurology.org/subscribers/advertise

Neurology ${ }^{\circledR}$ is the official journal of the American Academy of Neurology. Published continuously since 1951, it is now a weekly with 48 issues per year. Copyright . All rights reserved. Print ISSN: 0028-3878. Online ISSN: 1526-632X.

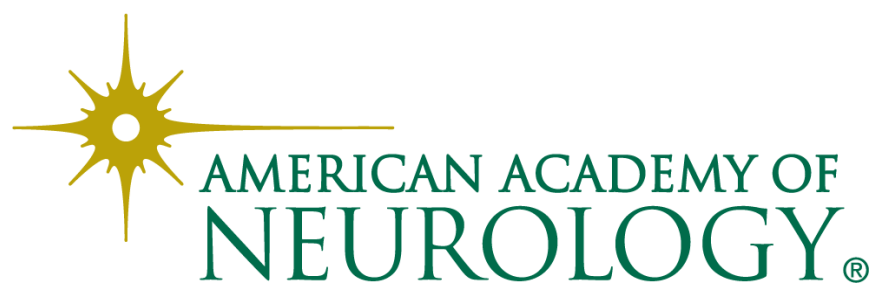

